\title{
MANFAAT DATAWAREHOUSE PADA RUMAH SAKIT ABC
}

\author{
Evaristus Didik M.; M. Awan Wibisono; Sucipto A.; Gusti Agung D. V. \\ Information Systems Department, School of Information Systems, Binus University \\ Jl. K.H. Syahdan No. 9, Palmerah, Jakarta Barat 11480 \\ didikmadyatmadja@yahoo.com
}

\begin{abstract}
This study is objected to analyze the current system to find the problems being faced by ABC Hospital and propose alternative solutions. Additionally, it aims to generate information needed by the hospital management to design a data warehouse according to the information needs. The research method used is the analysis and design of data warehouse by Kimball and Ross cited by Connolly and Begg, known as Nine-Step Methodology. The result obtained is a data warehouse application with a multidimensional historical data that can assist the hospital management in decision making. Designing data warehouse at ABC Hospital makes enterprise data into concise and can be viewed from several dimensions that help users analyze data for strategic decision quickly and accurately.
\end{abstract}

Keywords: data warehouse, design, hospital

\begin{abstract}
ABSTRAK
Tujuan penulisan ini adalah menganalisis sistem yang sedang berjalan untuk menemukan permasalahan yang sedang dihadapi oleh Rumah Sakit ABC dan mengusulkan alternatif pemecahan masalah serta menghasilkan informasi yang dibutuhkan oleh pihak manajemen rumah sakit dengan merancang data warehouse sesuai dengan kebutuhan informasi. Metode Penelitian yang digunakan adalah analisis dan perancangan data warehouse menurut Kimball dan Ross yang dikutip oleh Connolly dan Begg yang dikenal dengan Nine-Step Methodology. Hasil yang didapat adalah sebuah aplikasi data warehouse yang dapat menyajikan data historis secara multidimensional sehingga dapat membantu pihak manajemen di rumah sakit dalam mengambil keputusan. Perancangan data warehouse pada Rumah Sakit ABC menjadikan data perusahaan menjadi ringkas dan dapat dilihat dari beberapa dimensi yang bertujuan membantu pengguna untuk menganalisis data yang ada untuk pengambilan keputusan yang bersifat strategis secara cepat dan tepat.
\end{abstract}

Kata kunci: data warehouse, perancangan, rumah sakit 


\section{PENDAHULUAN}

Teknologi Informasi di perusahaan bukan hanya sebagai aset perusahaan yang merupakan pendukung terbesar perusahaan dalam mencapai keunggulan yang kompetitif, tetapi juga sebagai sumber daya yang esensial dalam perusahaan-perusahaan lain. Peran informasi antara lain dapat digunakan untuk menentukan suatu prioritas, menilai alternatif, membuat suatu program, mengimplementasikan dan memonitoring, mengevaluasi serta menganalisis situasi atau keadaan di rumah sakit (Ery Rustiyanto. 2010).

Rumah Sakit ABC menerapkan sistem berbasis komputer pada transaksi sehari-harinya. Seiring berjalannya sistem berbasis komputer, data-data yang disimpan akan semakin banyak dan semakin kompleks untuk dilakukan pengolahan. Untuk mengatasi masalah tersebut, Rumah Sakit ABC menyadari peranan penting dari data warehouse yang dapat memberikan informasi yang cepat dan akurat sehingga dapat menjadi pendukung dan acuan dalam pengambilan keputusan bagi para eksekutif.

Data warehouse merupakan suatu tempat penyimpanan data dalam jumlah besar yang digunakan untuk mendukung pengambilan keputusan. Menurut Inmon (2005, p29) data warehouse adalah sebuah orientasi subjek, terintegrasi, tidak volatil, dan variasi waktu dari sekumpulan data dalam mendukung keputusan manajemen. Data warehouse mengandung butiran-butiran data korporat. Data dalam data warehouse bisa digunakan untuk banyak kebutuhan yang berbeda, termasuk untuk memperkirakan kebutuhan yang akan datang dimana saat ini belum diketahui. Sementara menurut Kimball dan Ross (2004), data warehouse adalah sebuah sistem yang mengekstrak, membersihkan, menyesuaikan, dan menyampaikan sumber data kedalam sebuah tempat penyimpanan data dimensional dan kemudian mendukung dan mengimplementasi query dan analisis untuk tujuan pengambilan keputusan.

Berdasarkan penelitian yang telah dilakukan, ditemukan beberapa masalah sebagai berikut: (1) sistem pelaporan dan informasi yang ada pada Rumah Sakit masih terpisah-pisah, terutama apabila pihak eksekutif ingin melihat perbandingan infomasi pada tahun-tahun sebelumnya untuk jangka waktu yang lama, sehingga sulit untuk mendapatkan informasi yang bersifat summary; (2) laporan yang dihasilkan hanya menampilkan informasi dari dua dimensi saja. Untuk membandingkan informasi dari beberapa dimensi maka eksekutif harus membandingkannya secara manual; (3) lambat untuk mengakses data-data pada tahun sebelumnya sehingga keputusan yang diambil tidak optimal karena perusahaan masih mengambil data dari data operasional.

Untuk mengatasi masalah yang terjadi di Rumah Sakit ABC, diusulkan untuk membangun sebuah aplikasi data warehouse. Tujuan dari penelitian ini adalah: (1) menganalisis Physical design pada Database Rumah Sakit ABC untuk merancang data warehouse; (2) mengidentifikasi kebutuhan informasi berdasarkan visi dan misi yang dibutuhkan pihak eksekutif Rumah Sakit ABC yang nantinya berguna untuk perancangan data warehouse; (3) merancang dan membuat aplikasi data warehouse.

Aplikasi data warehouse yang dibuat diharapkan dapat membawa manfaat sebagai berikut: (1) informasi yang akan ditampilkan dapat bersifat summary sampai mendetail yang memungkinkan pengguna untuk memperoleh informasi yang bersifat summary sesuai dengan kebutuhan; (2) para eksekutif dapat memperoleh laporan yang memiliki beberapa dimensi dan dapat memilih data yang ingin ditampilkan; (3) pengambilan data historis tidak menggunakan data operasional sehingga lebih mudah dan cepat dalam mengakses data yang akan digunakan untuk pengambilan keputusan. 


\section{METODE}

\section{Pengumpulan data}

Metode pengumpulan data yang digunakan pada perancangan data warehouse ini antara lain dengan: (1) wawancara untuk memperoleh informasi mengenai proses bisnis yang berjalan pada Rumah Sakit ABC, kebutuhan user, dan permasalahan yang dihadapi oleh Rumah Sakit ABC; (2) uji dokumentasi dengan melihat formulir-formulir dan database yang sedang berjalan di rumah sakit.

\section{Perancangan}

Perancangan Data warehouse pada Rumah Sakit ABC menggunakan centralized Data warehouse (Data warehouse yang terpusat). Sumber data yang terdapat pada database operasional Rumah Sakit ABC akan dipilih berdasarkan jenis pelaporan yang akan dibutuhkan oleh perusahaan, yang kemudian dikumpulkan dan diintegrasikan pada suatu tempat penyimpanan besar. Setelah terintegrasi barulah data digunakan oleh Kepala rumah sakit, Komite medik, dan Komite perawatan.

Dipilihnya arsitektur terpusat karena memiliki beberapa keuntungan, yaitu: (1) konsistensi data sangat tinggi karena data-datanya sudah diintegrasikan terlebih dahulu; (2) mempermudah maintenance dari Data warehouse, termasuk pemantauan (Controlling), karena memiliki penyimpanan yang khusus. Berikut arsitektur data warehouse yang dibuat (Gambar 1).

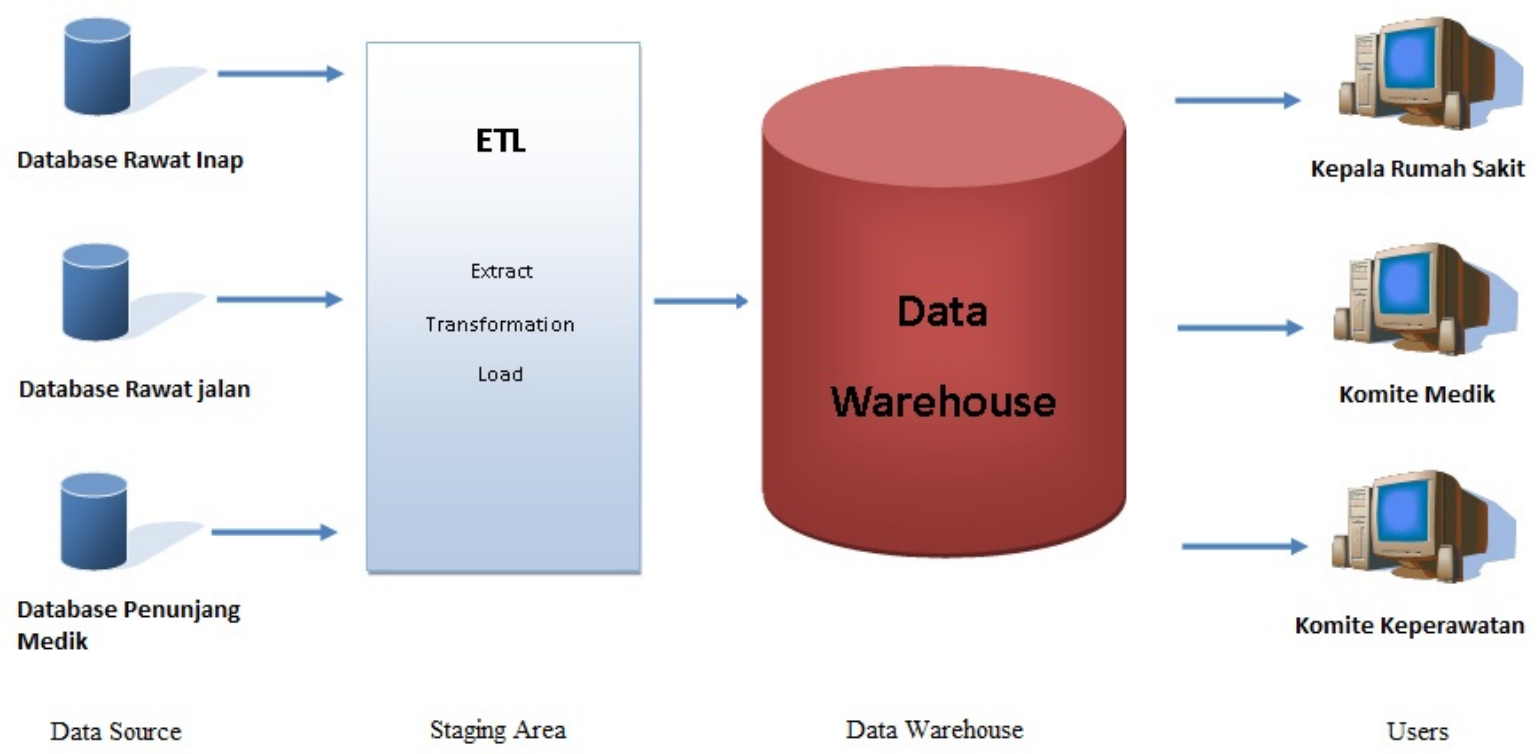

Gambar 1. Arsitektur Data warehouse pada Rumah Sakit ABC.

Metode perancangan yang digunakan adalah nine-step methodology menurut Kimball yang dikutip oleh Connolly dan Begg (2010), yaitu: (1) choosing the process. Berikut proses yang ada pada Rumah Sakit ABC yang akan dipilih untuk perancangan Data warehouse: Proses Rawat Jalan, Proses Rawat Inap, Proses Penunjang Medik; (2) choosing the grain. Memilih grain berarti menentukan apa yang sebenarnya direpresentasikan oleh record dalam tabel fakta. Berikut adalah grain yang ada dalam perancangan Data warehouse Rumah Sakit ABC: Grain Proses Rawat Jalan, Grain Proses Rawat Inap, Grain Proses Penunjang Medik; (3) identifying and conforming the dimension: Rawat 
Jalan, Rawat Inap, Penunjang Medik; (4) choosing the facts. Di tahap ini akan dilakukan pemilihan fakta yang akan digunakan pada Data warehouse. Fakta yang ada akan diproses dan ditampilkan dalam bentuk grafik. Berikut adalah fakta-fakta yang akan digunakan: Fakta rawat jalan, Fakta rawat inap, Fakta penunjang medik; (5) storing pre-calculation in fact table. Kalkulasi awal terdapat pada tabel fakta. Pre-kalkulasi yang terdapat dalam tabel fakta meliputi: fakta rawat jalan, yaitu jumlah rawat jalan dari keseluruhan kunjungan rawat jalan; fakta rawat inap, yaitu jumlah rawat inap dari keseluruhan kunjungan rawat inap; dan fakta penunjang medik, yaitu jumlah penunjang medik dari keseluruhan kunjungan penunjang medik; (6) rounding out the dimensions table: dimensi waktu, dimensi pasien, dimensi poliklinik, dimensi dokter, dimensi kamar, dimensi penyakit, dimensi penunjang medic; (7) choosing the duration of the database. Durasi dari database Rumah Sakit ABC yang dimasukkan ke dalam Data warehouse ditampilkan pada Tabel 1. Data yang masuk ke dalam Data warehouse dimulai dari tahun 2007 dimana pihak manajemen rumah sakit meminta ketersediaan data untuk menganalisa endemi (penyakit musiman) yang terjadi dalam kurun waktu tertentu sejak 5 tahun silam; (7) tracking slowly changing dimension. Flow Chart Perubahan Dimensi Secara Perlahan. Penggambaran jika terjadi perubahan dimensi dapat dilihat pada Gambar 2; (8) Deciding query priorities and the query modes. Proses Extract, Transformation, and Load (ETL). Proses ETL akan dilakukan setiap hari dan akan dilakukan oleh staf TI di rumah sakit. Tetapi apabila terjadi perubahan data pada basis data operasional yang merupakan sumber dari tabel dimensi, maka akan dilakukan ETL saat terjadi perubahan tersebut; (9) Proses Backup. Proses backup akan dilakukan satu minggu sekali oleh staff TI sebelum dilakukan proses ETL. Backup dilakukan untuk mengantisipasi kegagalan dalam proses ETL dan membuat salinan data ke media penyimpanan yang lain untuk mengurangi resiko kehilangan data karena kerusakan hardware, kesalahan user, ataupun bencana alam. Backup yang dilakukan menggunakan tipe full backup dimana data-data pada data warehouse akan disalin ke media penyimpanan lain secara keseluruhan, dimana jika terdapat penambahan data, backup akan menyalin keseluruhan data dan akan me-replace data-data backup yang sebelumnya.

\section{HASIL DAN PEMBAHASAN}

Setelah melakukan analisis terhadap proses bisnis dan database pada Rumah Sakit ABC, informasi yang dibutuhkan oleh para eksekutif adalah sebagai berikut: (1) informasi mengenai rawat jalan, meliputi jumlah transaksi rawat jalan berdasarkan periode tahun, jenis pasien yang paling banyak melakukan transaksi rawat jalan, poliklinik yang paling banyak dikunjungi, dokter yang paling banyak melakukan pemeriksaan rawat jalan, penyakit yang paling banyak diderita pasien rawat jalan, kategori umur yang paling banyak melakukan rawat jalan; (2) laporan mengenai rawat inap, meliputi jumlah transaksi rawat inap berdasarkan periode tahun, golongan pasien yang dirawat, penyakit yang paling banyak diderita pasien rawat inap, Dokter Spesialis yang paling banyak melakukan pemeriksaan, kategori umur yang paling banyak melakukan rawat inap, kelas kamar yang paling banyak digunakan; (3) laporan mengenai penunjang medik, meliputi jumlah transaksi pemeriksaan penunjang medik berdasarkan periode tahun, kategori umur yang paling banyak melakukan pemeriksaan laboratorium, Jenis Pemeriksaan Penunjang Medik yang paling banyak dilakukan.

\section{Skema Bintang (Star Scheme)}

Skema bintang yang dirancang mencakup 3 fakta, Rawat Jalan, Rawat Inap, dan Penunjang Medik. Skema bintang dibuat berdasarkan tabel pada rancangan ERD usulan. Ada 3 fakta yang diusulkan dan dibuat menjadi skema bintang yaitu Fakta Rawat Jalan, Fakta Rawat Inap, dan Fakta Penunjang Medik. Dalam setiap dimensi masing-masing dibuat primary key baru yang dinamakan surrogate key untuk dihubungkan pada tabel fakta sebagai penanda unik baru yang bukan merupakan turunan dari tabel manapun. Kemudian dimensi pada setiap skema bintang diambil berdasarkan tabel 
pada ERD usulan tetapi hanya beberapa atribut tertentu yang dibutuhkan dan yang nantinya akan digunakan sebagai pembanding dalam pengambilan keputusan oleh pihak manajemen (Gambar 3).

\section{Form Pivot dan Chart}

Form Pivot \& Chart (Gambar 4 - 6) ini berisi tampilan hasil transformasi Data warehouse dalam bentuk grafik. Dalam form ini user dapat mengatur tampilan sesuai keinginan berdasarkan menu yang disediakan dalam form, seperti chart type untuk memilih tipe chart. Untuk menampilkan grafik dari data yang ada, user hanya perlu melakukan drag and drop dari pilihan dimensi yang tersedia di atas, untuk kemudian dipindahkan ke bawah, selanjutnya user tinggal melakukan block pada data dalam tabel yang kemudian akan muncul pada kolom graphic tepat di bawah tabel yang tersedia.

Tabel 1

Durasi Database

\begin{tabular}{|c|c|c|l|c|}
\hline Nama Aplikasi & Database & $\begin{array}{l}\text { Database ada } \\
\text { sejak tahun }\end{array}$ & $\begin{array}{l}\text { Data yang } \\
\text { masuk ke Data } \\
\text { Warehouse }\end{array}$ & $\begin{array}{l}\text { Data dalam } \\
\text { Data } \\
\text { Warehouse }\end{array}$ \\
\hline Aplikasi DWH & OLTP & 2002 & $2007-2011$ & 5 Tahun \\
\hline
\end{tabular}

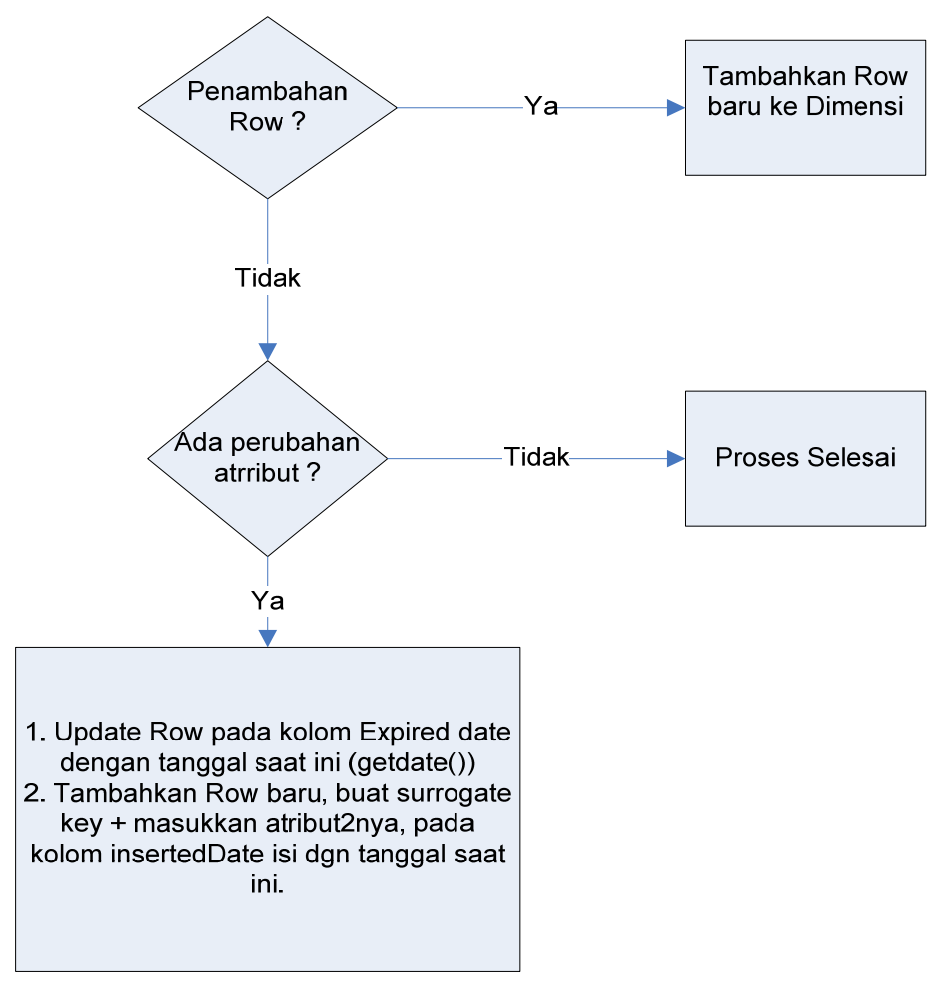

Gambar 2. Flow chart perubahan dimensi perlahan. 


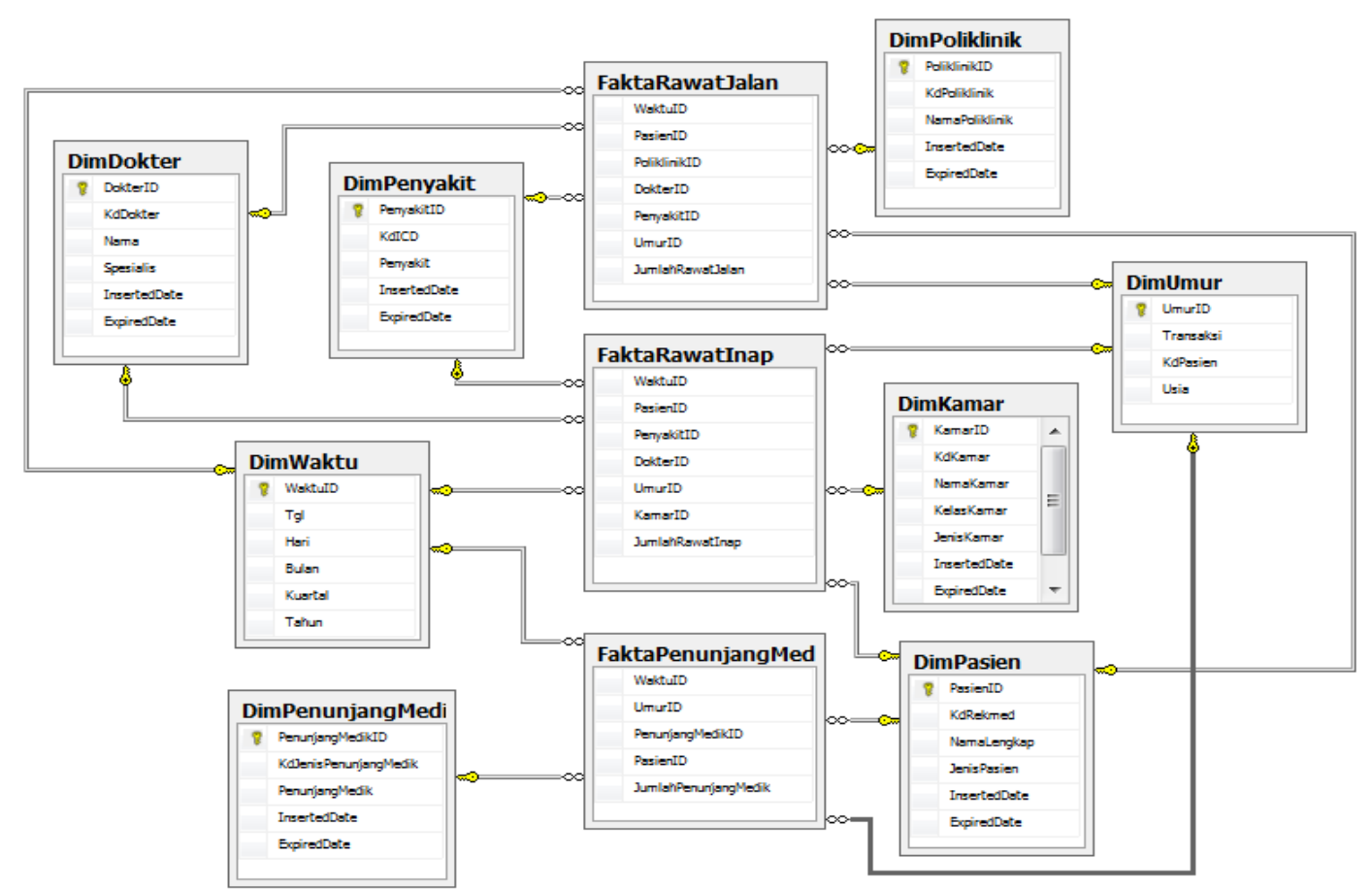

Gambar 3. Dimensional model pada data warehouse Rumah Sakit ABC.

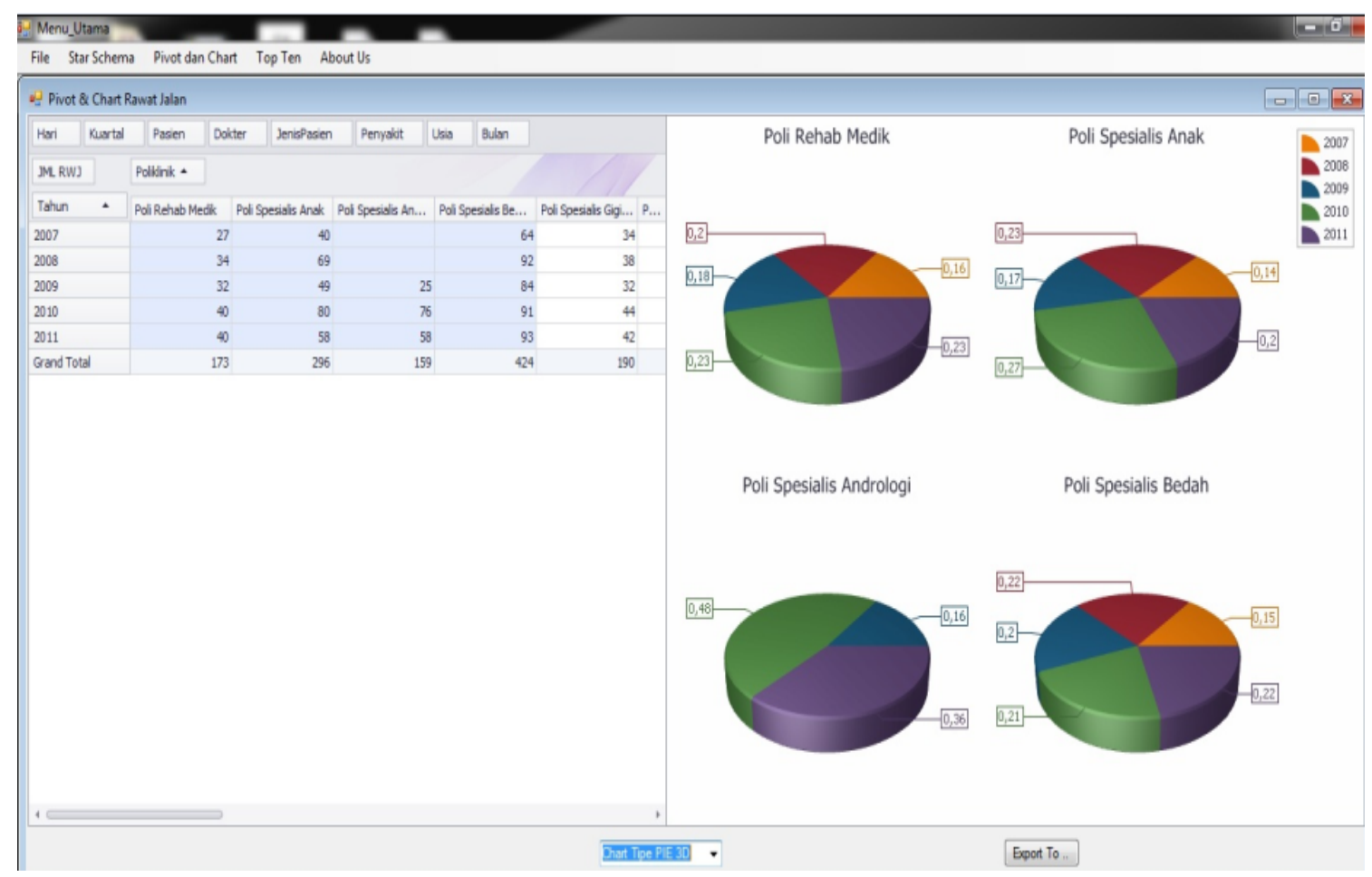

Gambar 4. Rancangan interface pivot Rawat Jalan. 


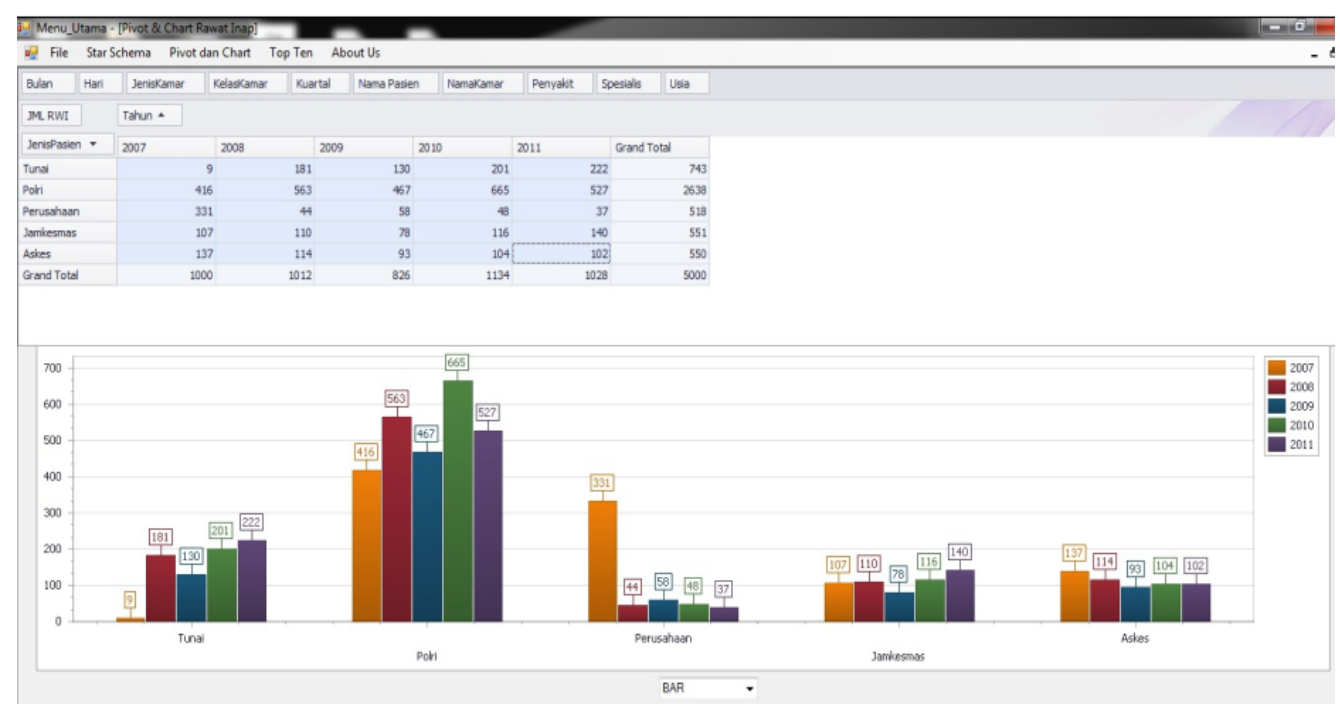

Gambar 5. Rancangan interface pivot Rawat Inap.

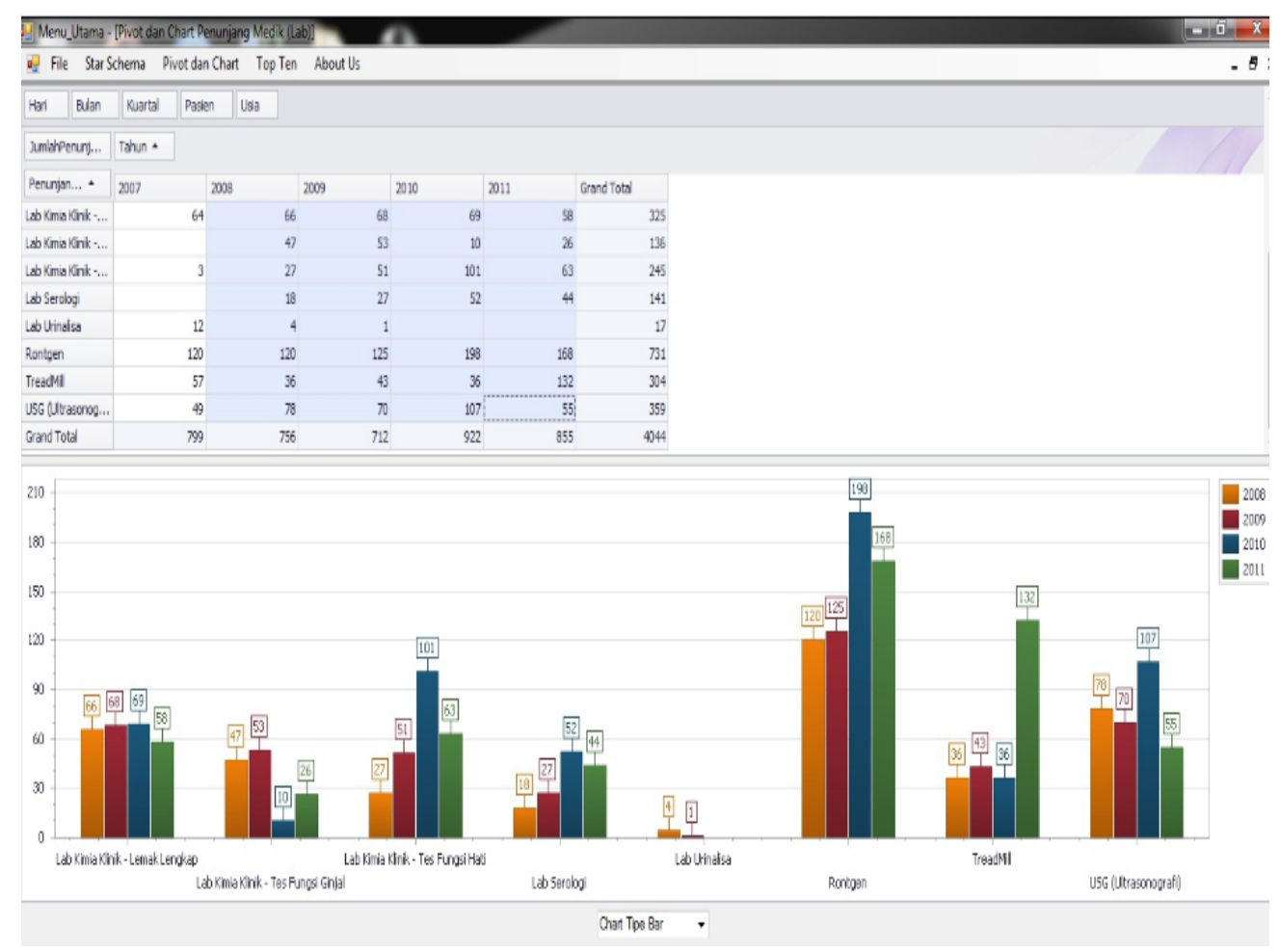

Gambar 6. Rancangan interface pivot Penunjang Medik.

\section{PENUTUP}

Setelah melakukan analisis pada Rumah Sakit ABC yang kemudian dilakukan perancangan data warehouse, dapat ditarik beberapa kesimpulan sebagai berikut: (1) dengan dibuatnya Data warehouse pihak manajemen Rumah Sakit ABC dapat mengambil keputusan dengan lebih cepat dan cermat karena database yang ada sudah diperbaiki dan grafik yang ditampilkan pada Data warehouse 
membuat tampilan report menjadi lebih simpel dan kompak, memudahkan para eksekutif untuk membacanya; (2) data warehouse yang dibuat merupakan hasil proses data yang memiliki dimensi yang bervariasi, sehingga pihak manajemen Rumah Sakit ABC mendapatkan sudut pandang yang lebih bervariasi dalam melakukan proses pengambilan keputusan; (3) dengan dibuatnya data warehouse ini, pihak manajemen Rumah Sakit ABC mendapatkan summary dari data yang ada sehingga pihak eksekutif dapat mengambil keputusan dengan lebih cepat dan tepat.

\section{DAFTAR PUSTAKA}

Connolly, Thomas dan Begg, Carolyn. (2010). Database Systems: A Practical Approach to Design, Implementation, And Management (fifth edition). Boston: Addison Wesley.

Inmon, W.H. (2005). Building the Data warehouse (fourth edition). Indianapolis: Wiley.

Kimball, Ralph. and Ross, Margy.(2002). The Data Warehouse Toolkit: The Complete Guide to Dimensional Modeling (second edition). Toronto: John Wiley and Sons.

Rustiyanto, Ery. (2010). Sistem Informasi Manajemen Rumah Sakit Yang Terintegrasi. Yogyakarta: Gosyen Publishing. 